\title{
Behavioural-humanistic model of soft competitiveness of enterprises
}

\author{
Michat AdAM LeŚNIEWSKI ${ }^{1}$
}

Jan Kochanowski University in Kielce, Institute of Management

\begin{abstract}
One of the fundamental problems faced by companies in the market economy is competitiveness. It can be shaped in various ways in order to achieve the desired goals. Soft competitiveness is one of such ways of shaping competitiveness and it originates from human resources, i.e. employees who contribute to the development of an organisation (enterprise). This article presents a behavioural-humanistic model of soft competitiveness of enterprises. The following assumptions have been made: Employees (human resources) are the source of soft competitiveness (thesis 1) and soft competitiveness is of a behavioural-humanistic nature (thesis 2). The theses presented have been interpreted with the use of the literature of the subject.
\end{abstract}

Paper type: conceptual article

Keywords: behavioural-humanistic model of soft competitiveness of enterprises, behaviourism, humanism, soft competitiveness

\section{Introduction}

The basis for the functioning of enterprises and other organisations is man (employee) without whom the organization cannot exist (Jedynak, 2010). The employee is both the source of successes and failures of the organization. A general look at employees from the point of view of the management of a given entity demands that they be divided into two basic groups: executives (serial employees) and managers (decision makers, responsible for the management of the organisation).

${ }^{1}$ michaladam.lesniewski@wp.pl; konkurencyjność.com.pl 
One of the views presented in this paper is that the man himself decides about the value of anything. This view originates from the philosophical thought of Protagoras (representative of Greek philosophy). Man is the measure of all things (Eukomski, 2000, p. 243). When translating the presented view into the problem of the organization's competitiveness from the point of view of the manager as a decision-maker (implementing the management process), one can say that the manager decides about the competitive factors contributing to the competitive advantage of the enterprise.

The manager and what he represents is reflected in competitiveness understood as factors (elements) connected with the organization and contributing to the creation of a competitive advantage. It should be mentioned that managers must actively cooperate with their subordinates, which contributes to positive synergies. The clearest picture of competitiveness can be obtained by perceiving the manager as a behavioural-humanistic being. The manager provides and implements competitiveness and a competitive advantage. As a behavioural-humanistic entity, the manager is part of the soft competitiveness model. This perception of the manager and executive employee highlights the qualitative aspect of the organisation.

The aim of the study is to present the concept of the behavioural-humanistic model of soft competitiveness of enterprises. The study assumes that employees (human resources) are the source of soft competitiveness (1) and that soft competitiveness is of a behavioural-humanistic nature (2). The theses presented have been developed on the basis of the interpretation of the subject literature, which makes use of, among others, the following: logical reasoning (logical thinking) and perception, allowing to combine various aspects into one compact whole and providing the image of the reality surrounding a given author. This method makes it possible to present the author's point of view. In this method, the following are used: theoretical experiences, practical experiences and theoretical-practical experiences (combination of theory with practice). This method is widely used in the world of science and business practice, providing the basis for reactive or proactive human activity. In logical reasoning - from the perspective of the author of the study - this method can be referred to as the queen of methods.

\section{Behaviouralism and humanism in the management of people}

The functioning of management as a science and business practice is based on many concepts that refer to different sources of philosophy as perception and treatment of people (Oczkowska, 2014).

Human beings can be approached in a variety of ways, as illustrated by the behavioural school and humanistic school, among others. The behavioural school 
(behavioural concept, behavioural approach, behavioural trend) is based on a reductionist human model which is subject to stimulation leading to a predictable and programmable reaction (McGee \& Rennie, 2012; Miner, 2015). This school perceives man as an individual behaving in different ways depending on the situation or conditions in which a given person finds themselves. The second school is the humanistic school in which the manager (leader, mentor) focuses on the individual needs of a person, supporting their development (Raiden, Dainty, \& Neale, 2007; Taormina, 2009). Both the behavioural school and the humanistic school make a major contribution to the development of human resources. In the practice of human resources management, both schools should be taken into account, i.e. one should adopt an integrated approach (integrated school), because man (employee) is both a behavioural and humanistic person. The integrated approach combines the two concepts into one compact whole, depicting man as a behavioural-humanistic being. Incentives, situations, conditions and needs constitute an integrated image of the human being.

The behavioural trend officially came into being in 1913 as a result of the Watson's behavioural manifesto, but it had already had its precursors in figures, such as, Pawłow or Thorndike (Stachowski, 2000). In his analysis, Watson focused on factors that improve human functioning. What he recognized as the purpose of psychology - as an experimental science - was the control of behaviours and the possibility of predicting them (Ziółkowska, 2008). The Watson's concept, an extremely reductionist concept, is called the psychology of stimulus and reaction. According to this concept, the body is influenced by many different stimuli, causing physiological, physical, emotional and even mental reactions (Matusewicz, 2006). Watson claimed that the environmental impact is so omnipotent that, regardless of internal factors, it can influence any specialist even if their proficiency is based on their talent (e.g. artistic, musical) (Trojan, 2014). Another representative of the behavioural school is Skinner, who drew attention to the rewards and punishments that shape the individual's behaviour and stressed that stimulus deprivation leads to pathology in the individual's behaviour (Ziółkowska, 2008). The example of a person who may experience this situation is a person who is mobbed, who is not assigned any tasks, whose communication is limited, and who is, therefore, isolated from the stimuli characteristic of the work environment. One can also rely on the regularities related to the use of reinforcements when creating incentive systems. The meta-analysis of data from many American studies has shown the dominance of the influence of financial incentives (particularly those dependent on results) on work productivity, reduction of absenteeism and staff turnover over non-financial factors (Tyszka \& Zaleśkiewicz, 2004). This proves that the employee behaves in a certain way, because he or she has experienced many positive and negative reinforcements that have shaped their attitude. Every behaviour is conditioned by, among other things, reinforcements and attitudes towards the problem. Another representative of the behavioural school, referring at the same time to a cognitive ap- 
proach, was Bandura, the creator of the theory of social learning. He believed that in order to understand human behaviour, it was not possible to rely solely on learning theories, but one should also take into account the mutual interaction of the social environment. People are shaped by the environment and actively create it. Apart from self-assessment, it is also the source of reinforcements. Depending on their abilities, they learn by observing the interactions of other people with the environment (Ziółkowska, 2008). The theory of Bandura was used, among others, in experiments explaining the economic socialisation of children (Rolad-Lévy, 2004).

The achievement of the behavioural school is widely used in psychological practice, also in solving social problems in organizations, and its special form is organizational behaviour management. Researchers of this trend have shown that the application of behavioural procedures has a positive impact on employee behaviours and eliminates the undesirable ones (Suchowierska, 2008). Behaviouralism often allows effective treatment of pathological behaviours (e.g. overcoming addictions such as workaholism, modifying dangerous behaviours from the point of view of an organisational order) and it is also a method of exerting positive influence in the process of education (also professional education) and upbringing. Training methods based on behavioural knowledge (e.g. workstation training, modelling of behaviour) let an employee improve his/her professional competences, feel more valued and give his or her skills a specific meaning and purpose. Moreover, the research carried out in this field, especially in connection with cognitive concepts, shows how people value gratification (also in the workplace), which induces them to make decisions that are desirable from the point of view of influencing decisions and which shapes their various economic behaviours (saving, risk-taking, insurance) (Suchowierska, 2008). Behaviouralism aims to emphasize human values in the environment in which it functions.

Apart from behaviourism, there is a humanistic school (humanistic approach, humanistic concept) whose main representatives are Maslow and Rogers. Their views were the reaction to the demonic vision of psychoanalysis and reductionism of behaviourism. Maslow conducted discussions on healthy and creative individuals; he demanded that science depart from the analysis of a sick and dysfunctional man, and focus on what is good, optimistic and what builds the potential of individuals. While conducting research on self-realising persons, he created the psychological portrait of a positive individual, trusting in himself and others (Hall \& Lindzey, 2001). He called for a holistic and dynamic approach to individuals, as only such an approach provides a deep understanding and lasting solution to possible problems (Maslow, 2006). Spending some time with an individual (worker, pupil, patient) can prevent him or her from being labelled and stigmatized in an abusive way as a fierce, bold, unpredictable person, which to a large extent determines their future functioning. Maslow formulated his proposal for business under the name of eupsychian management, which is based on a humanitarian approach to people (in its centre there is a man with his individual needs, a human 
and his perspective). In the longer term, such a philosophy of action is also supposed to bring financial benefits (Cox, 2006). The second "father" of the humanistic approach, Rogers, is the creator of the client-oriented non-directive therapy. Its basis is an empathetic bond between the facilitator and the client. Its principles are widely used in counselling, management of meeting groups and resolution of group conflicts (Hall \& Lindzey, 2001). This therapy is based on a genuine relationship between a student and teacher and is widely used in trainings of medical personnel, career guidance, managerial training, community animators and various cultural circles (Rogers, 1991). Thanks to the humanistic concept, in the sphere of business it was also possible to look at the employee differently, seeing his individuality, creativity and willingness to grow.

The main idea of the humanistic concept is that man is a unique individual, integrated into the environment in which he lives; human development is determined by the factors inherent in him and beyond. Man strives for self-fulfilment and by the very nature of his existence he is good and has a positive attitude towards the world around. His behaviour is conditioned by the present, what he represents here and now, because the man who lives in the past will not achieve full development.

Behavioural and humanistic concepts are the basis of shaping human development also as at a workplace, which in turn contributes to building the competitiveness of the organisation (enterprise). It can be said that man is the creator of broadly understood development, including the competitiveness of an organization. Man is both the beginning and end of an organisation. Considering the organization's competitiveness in the context of man, one can talk about the behavioural-humanist competencies that can be regarded as specific competitiveness.

\section{Competitiveness of enterprises}

Competitiveness is a complex, multi-faceted issue and, depending on the entity in relation to which it is researched, is characterised by various traits and often different methodology (Adamkiewicz-Drwilo, 2002, p. 9).

Competitiveness is one of the so-called theoretical concepts. It means that it is not a sign of any particular person or thing, nor anything that can be imagined as things and persons. In fact, there are no directly identifiable determinants. In order to clarify the meaning of this concept, it is necessary to break it down, which means distinguishing between the dimensions of competitiveness. Competitiveness includes various factors contributing to generating a competitive advantage on the market. Competitiveness is characteristic of a given organisation.

Competitiveness can be understood in various ways (Adamkiewicz-Drwiło, 2002, pp. 63-69). On the one hand, it is a trait, attribute, outcome, result (resultant approach), and, on the other hand, a process (functional approach). Its sec- 
ond meaning should be associated with achieving the trait, attribute or result, i.e. competitiveness. Therefore, it is a process through which one has to go in order to become competitive (Gorynia, 2002, pp. 49-50; Kusz, Kusz, \& Sobolewski, 2009, p. 364). This is, in other words, competing (Gorynia, 2009, p. 48). Competitiveness, in its first meaning, is most often generalised against the background of economic issues and is a concept that refers to the market economy. The essence of this economy lies in the fact that the participants of economic life compete at different levels. To put it simply, it can be assumed that competitiveness means being able to compete, i.e. to act and survive in a competitive environment. Competitiveness in the process (functional) sense is in fact inseparable from competitiveness in the attribute (resultant) sense. Process competitiveness leads to attribute-based competitiveness (Gorynia, 2009, p. 50). Competitiveness is mainly a relative attribute, which means that it assumes a certain type of relationship between the object, about which something is claimed, and other objects. Competitiveness can be classified as a relative characteristic which is referred to with the use of comparative properties. Comparative properties of objects involve the attribution of certain characteristics to objects by comparing them with other objects or with a given standard of comparison (e.g. an average for the whole group).

Competitiveness can be seen as the purpose of the company's activity (Adamkiewicz-Drwiłło, 2002, p. 57). It means meeting the needs of customers in a more efficient way than other companies (Świtalski, 2005, pp. 165-166). Companies that seek to sustain their competitive position in the marketplace must continuously invest in innovation and the development of their products and services or offer clear price benefits. The best companies successfully combine knowledge of the future of the market with well-established competence-based management. They put emphasis on the development of an organisational culture with elements that drive innovation and entrepreneurship, where top management members are the main initiators of pro-development changes (Bailom, Matzler, \& Tschemernja, 2009, pp. 13, 59-80).

Apart from the organizational culture, knowledge, which becomes a strategic resource on the basis of which one can build a competitive advantage in modern markets (competitive advantage thanks to knowledge), is an inherent factor of change. Knowledge is also known as the so-called specific resource "entangled" in the whole context of the remaining "soft" resources (Leśniewski, 2015), especially, such as, organisational culture, internal relations within the organisation, systems of motivating, communicating and interactions and relations with the environment. Many of these resources - together with the knowledge itself - are created as a result of a long-term accumulation of experience gathered in specific socioeconomic, technological, legal, political, cultural conditions in which a given enterprise functions or operates (Stankiewicz, 2006, p. 14).

Competitiveness of the enterprise is the effect of synergistic-complementary interaction of internal factors (within the enterprise) and external factors (outside 
the enterprise) as well as the mechanism of mutual interpenetration of these factors. The high level of competitiveness of the company reflects not only the success of the management staff with skilful use of knowledge, but also the strength and efficiency of the national economy and various externalities that the company can and should use. Factors that affect the competitiveness of an enterprise should be considered in an integrated approach, i.e. by perceiving their mutual interrelationships and interdependencies. The key determinants of competitiveness of modern enterprises are interactive in nature, they are a combination of interlinked factors that make up a multidimensional space. They should not be seen as single, isolated variables, but as a set of mutually dependent elements (e.g. soft factors, hard factors) that occur within the same time horizon and permeate one another.

One of the forms of competitiveness of an enterprise is soft competitiveness, which emphasizes the human being and anything that is related to him. Soft competitiveness can serve as an example of the operational and strategic development of an economic entity. It should be stressed that the organisation will achieve significant benefits from shaping soft competitiveness in a strategic time dimension rather than an operational dimension, because the components that create it, such as, trust, cooperation or skills etc., are pro-developmental in the long run.

\section{Soft competitiveness of enterprises}

Soft competitiveness is a set of factors that can be subjected to the process of becoming more flexible (plasticisation). The process is based on a relatively plausible change in the properties, type and character of a given factor (e.g. in relation to organisational culture it may be a change of culture type from clan culture to adhocracy culture; in the case of motivating - a change of motivation from type everyone has equally contributed to individual motivation of type you have contributed to the company's profit, you receive a certain benefit, you as an employee, you as an individual (Leśniewski, 2015, p. 231).

Soft competitiveness plays an important role in building and shaping the overall competitiveness of enterprises. Soft competitiveness can be seen as a detailed, specialised form of competitiveness of an economic operator. This form of competitiveness can be realized in any organization that prefers and appreciates quality employees while, at the same time, recognizing their intellectual potential in the organization.

Soft competitiveness through the exposition of human resources and human factors such as, for example, competence or knowledge contributes to the effectiveness and efficiency of behavioural advantage of economic operators. Building and shaping soft competitiveness and, therefore, behavioural competitive advantage requires intellectual involvement of the company's employees, especially the man- 
agement staff (Leśniewski, 2015, p. 231). In order for an economic entity to be able to base its development on soft competitiveness, it must have the so-called quality workers, i.e. people who fully integrate with their intellectual potential into the structure of a given enterprise. These are the employees adapted to: work position, organisational unit, organizational department, management level, etc. with their skills, i.e. the right person, at the right place, at the right time and in the right organisation (Leśniewski, 2015, p. 232).

The author model of competitiveness of soft enterprises presented below (Figure 1) depicts the problem taking into account the interaction between internal and external environment. It takes into account the behavioural competitive advantage of enterprises, which is generated by factors of soft competitiveness. The potential possibilities of the analysed competitiveness depend on the feedback from the internal environment to the external environment. Each model element has

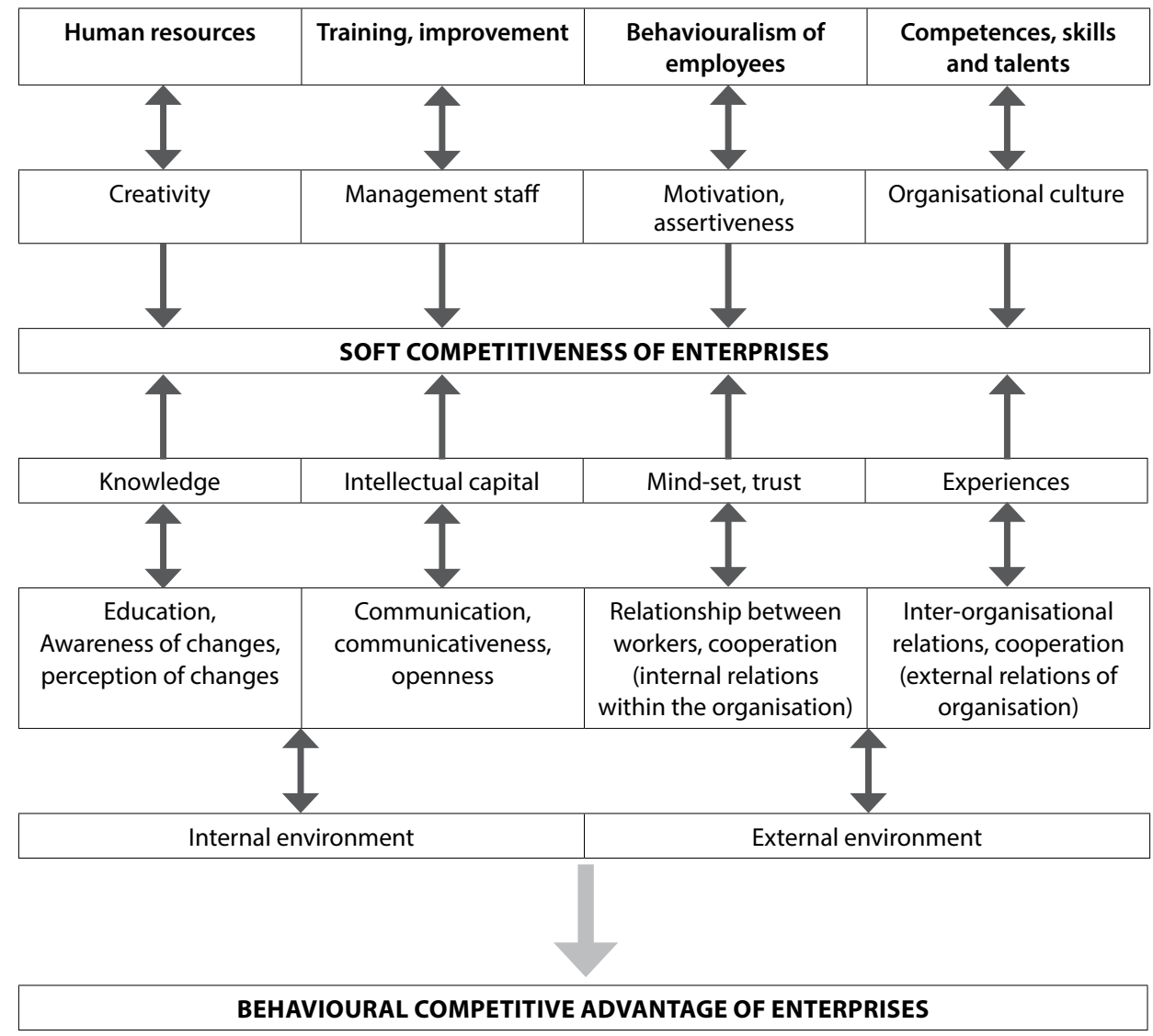

Figure 1. The model of soft enterprise competitiveness.

Source: Leśniewski, 2015, p. 233. 
a value which influences the overall value of the soft competitiveness of the organisation (enterprise). When building and shaping its soft competitiveness, an enterprise must determine which soft factor or factors constitute the core of the analysed competitiveness (e.g. employees knowledge, skills, experience or trust). The value of particular factors is not divided proportionally (e.g. $25 \%$ or $10 \%$ each) in relation to the overall soft competitiveness. There may be cases where one or the other factor represents more than $50 \%$ of the value in relation to all soft competitiveness, which means that they play a decisive role. Such factors may include creativity, motivation or experience of employees. These factors are created by the synergisticcomplementary system of competitiveness of soft economic entities (Leśniewski, 2015, p. 233).

The model is based on man and his perspective in the organization. Human resources are the first factor generating soft competitiveness. Human resources are the primary resource (Leśniewski, 2014, p. 62) of the organization, which is visible on the model of soft competitiveness and which constitutes the introduction of this model into the behavioural-humanistic aspect. The employees and, above all, their quality begin the process of building and shaping soft competitiveness and behavioural competitive advantage of enterprises. Therefore, the human resources process of the enterprise (organization) should be carried out by specialists in the field of human resources management. What kind of people (employees/workers) are employed plays an important role in shaping soft competitiveness and a behavioural competitive advantage. The employee must be such a great match for the enterprise that they can collectively be referred to as one body and one soul. The quality of human resources may stimulate or destimulate soft competitiveness. Whether a company will base its development on soft competitiveness depends on the quality of its employees.

The model shown in Figure 1 can be viewed in two ways: analytically or synthetically. Analytical model refers to the development of this competitiveness in one or more factors (e.g. the company cares only about the education of employees, or training or development of employees or trains them to develop certain skills). This view is accurate and secure when the company has a strong competitive advantage on the market. Synthetic model refers to the development of soft competitiveness in the area of all factors included in the model. In this perspective, the company should holistically consider the factors of its soft competitiveness (Leśniewski, 2015, p. 234).

In analytical and synthetic approaches, the economic entity should constantly monitor their factors of soft competitiveness. The experience of economic entities shows that the company should take into account both views (synthetic and analytical). Each of them contributes to soft competitiveness. In addition, the combination of approaches should be treated as an integrated approach to factors that create soft competitiveness (integrated approach). It is worth emphasising that each economic entity must develop its own, unique and difficult-to-copy model of soft 
competitiveness. Competitiveness factors contribute to the creation of a competitive advantage for an economic entity. Each soft competitiveness factor creates and shapes a specific behaviour of enterprises in relation to other market participants. This can be called a behavioural competitive advantage for companies. The behavioural competitive advantage of companies is about gaining an advantage over other market participants through taking a specific action that will be beneficial for the company and thus the goal will be achieved. The behaviour of an economic entity (Budzanowska-Drzewiecka, Marcinkowski, \& Motyl-Adamczyk, 2016) can be based on two main forms of market activities: cooperation and competition. For example, the type of organizational culture can make an enterprise favour collaboration, which means that an entity enters into market agreements (e.g. strategic alliances, clusters or other forms of cooperative market activity), or competes by winning or losing on the market (Leśniewski, 2015, pp. 234-235).

None of the soft competitiveness factors in the presented model can stand alone. There has to be a synergistic-complementary relation among them. Soft competitiveness factors, functioning together with other factors, generate bigger benefits for the company and, at the same time, complement one another (they create strong and lasting relationships with one another). It can be stated that the quality of soft competitiveness factors is the quality of behavioural-competitive advantage (Leśniewski, 2015, pp. 234-235).

The soft competitiveness model can be oriented towards various aspects of the company's functioning. One of these aspects is the behavioural-humanist perspective on the model of soft competitiveness.

\section{Behavioural-humanistic model of soft competitiveness of enterprises - conceptual model}

The basis for the functioning of every organisation is man (employee). The quality and number of employees creates a specific melange between various factors that characterise individual employees. Every development-oriented organization should choose man and his perspective in the organization as a focal point, i.e. adopt the concept of a forward-looking man. This concept is based on the fact that man sees and perceives the organisation as a place of their own and the organisation's development.

On the one hand, man is the basis, the foundation of the organization's development and, on the other hand, it is a cost-creating resource of the organization. This dichotomy requires a certain balance. The concept that forms the basis for such a balance is the behavioural-humanistic model of soft competitiveness of enterprises, in which man (employee) determines the quality of the development of the whole organisation (company). In this model, man (employee) is perceived as 
the person needed by the organisation (friend of organisation). In order to be seen in the organisation as a foundation for development, man should have clearly defined attributes and everything that shapes him. In this model, man is considered both as a behavioural being and a humanistic being influencing the elements of soft competitiveness with the aim of achieving a behavioural-humanistic competitive advantage of enterprises. Human behaviour and being human forms the qualitative picture of the reality of the organisation where man plays a leading role. The model shown in Figure 2 is bidirectional. The first direction of analysis starts with man (employee) and ends with the organization achieving a behavioural-humanistic competitive advantage (this direction is illustrated by an arrow pointing downwards on the far left) and the second direction of analysis starts with the enterprise achieving a behavioural-humanistic competitive advantage and ends with the finally-shaped man (employee) of the organization (this direction is illustrated by the arrow pointing upwards on the far right). In each direction of the analysis, the elements of soft competitiveness and interpersonal relations are taken into account. In this model, the internal and external environments of the company are mutually permeating.

The behavioural-humanistic model of soft competitiveness of enterprises is an author view of both the problem of the competitiveness of an economic entity and the functioning of man in an organization. In the model of the behavioural-humanistic soft competitiveness of enterprises, the starting point is man as a behavioural being having their dignity together with various attributes (humanistic). ${ }^{2}$ Man is the backbone of the organisation that grows thanks to a quality employee. Man being in an organisation (enterprise) influences its formation and organization influences the formation of man (employee). There is then a mutual relationship: man - organization and organisation - man. The employee responsible for the management process is a manager who, through other employees, changes the shape of the present and potential image of the organisation's reality. The manager, as an employee of the organisation, looks at it as a system (perceives the whole organisation) and sees the organisation as subsystems (specific groups of people and individual employees). The manager takes care of the factors of soft competitiveness of companies, knowing that these factors are shaped not only by the person, but also by the interpenetration of the internal and external environment. Finally, through factors of soft competitiveness, the economic entity achieves a current and/or potential behavioural-humanist competitive advantage over other companies. The achieved and shaped behavioural-humanistic competitive advantage influences factors of soft competitiveness, interpersonal relations and employees whose value shapes the life cycle of an enterprise.

2 It is possible to consider and analyse man in an organisation or to manage human resources in the light of the concept of behavioural man and the concept of humanistic man and in the light of the integrated concept, i.e. the behavioural-humanistic concept. 


\begin{tabular}{|c|c|c|c|}
\hline \multicolumn{4}{|c|}{ Man as an individual (employee) and his behavioural-humanistic attributes } \\
\hline \multicolumn{4}{|c|}{$\begin{array}{l}\text { - Employee (manager and subordinates) and his or her approach to work, diligence in the perfor- } \\
\text { mance of duties, positive attitude to work and people - employee quality } \\
\text { - Dignity and freedom of the employee, well-being of employees, positive attitude towards change } \\
\text { - Internal motivation and external motivation of employee } \\
\text { - Personality of employee } \\
\text { - Awareness of employee } \\
\text { - Personal fulfilment of employee } \\
\text { - Employee perspectives in the development of organization - noticeable contribution of the em- } \\
\text { ployee to the development of the company }\end{array}$} \\
\hline \multicolumn{2}{|c|}{ Interpersonal relations such as: Competition } & \multicolumn{2}{|c|}{ Interpersonal relations such as: Cooperation } \\
\hline \multicolumn{4}{|c|}{ The enterprise as a whole (system) - all employees - holistic viewpoint } \\
\hline \multicolumn{4}{|c|}{$\begin{array}{l}\text { The enterprise as groups and entities (subsystems) - individual groups of employees, individual } \\
\text { workers - detailed look }\end{array}$} \\
\hline \multicolumn{4}{|c|}{ nte } \\
\hline Human resources & Training, improvement & $\begin{array}{l}\text { Behaviouralism of } \\
\text { employees }\end{array}$ & $\begin{array}{l}\text { Competences, skills } \\
\text { and talents }\end{array}$ \\
\hline I & I & I & I \\
\hline Creativity & Management staff & $\begin{array}{l}\text { Motivation, } \\
\text { assertiveness }\end{array}$ & Organisational culture \\
\hline Y & Y & 平 & Y \\
\hline Knowledge & Intellectual capital & Mind-set, trust & Experiences \\
\hline I & I & I & 車 \\
\hline $\begin{array}{l}\text { Education, } \\
\text { Awareness of changes, } \\
\text { perception of changes }\end{array}$ & $\begin{array}{l}\text { Communication, } \\
\text { communicativeness, } \\
\text { openness }\end{array}$ & $\begin{array}{l}\text { Relationship between } \\
\text { workers, cooperation } \\
\text { (internal relations } \\
\text { within the organisation) }\end{array}$ & $\begin{array}{l}\text { Inter-organisational } \\
\text { relations, cooperation } \\
\text { (external relations of } \\
\text { organisation) }\end{array}$ \\
\hline $\boldsymbol{I}$ & I & 平 & 起 \\
\hline \multicolumn{2}{|c|}{ Internal environment } & \multicolumn{2}{|c|}{ External environment } \\
\hline $2 \mathrm{EL}$ & ENTS OF SOFT COMP & IVENESS OF ENTERP & ISES $\triangle$ \\
\hline
\end{tabular}

Figure 2. Behavioural-humanistic model of soft competitiveness of enterprises.

Source: own elaboration based on: Leśniewski, 2015, p. 233; Leśniewski, 2016a, pp.151-164; Leśniewski, 2016b, pp. 115-134. 


\section{Conclusions}

An enterprise that is subject to market rights must ensure that it permanently shapes its competitiveness, which contributes to the achievement of a competitive advantage. Competitiveness and a competitive advantage allow for the operational and strategic development of the enterprise. Through human resources (managers and subordinates) it is possible to shape soft competitiveness together with the behavioural competitive advantage of enterprises. In a detailed analysis, man appears to be a behavioural-humanistic individual. What creates a human being and how they behave influences the success or failure of an organization. The way management and subordinates implement the process of behaviouralization and humanisation of changes taking place in the organisation (enterprise) and beyond ultimately affects the competitiveness and competitive advantage of the economic entity.

The basis for constructing the objective and theses in this study is the quality of management staff and the quality of subordinates, who picture the quality of the economic entity. It can be said that the quality of employees contributes to the quality of the organisation. The management staff, as the entity implementing the management process, has a direct influence on the direction of soft competitiveness into the behavioural-humanistic area, while executive employees have an indirect influence by maintaining relations (cooperation) with managers.

The concept of the soft competitiveness model and the behavioural-humanistic model of soft enterprise competitiveness emphasize the importance and fundamentality of employees (human resources). The use of the method of interpretation of the literature subject gives rise to the following statements:

- the basic resource of the organisation are human resources (primary resource),

- human resources are the basis of the soft competitiveness model,

- the quality of human resources stands for the success or failure of the organisation,

- man (employee) is a behavioural-humanistic individual,

- the soft competitiveness model coming from man as the primary resource of the organisation takes the behavioural-humanistic form.

These statements confirm that:

- The source of soft competitiveness are employees (human resources) (thesis 1$)$.

- Soft competitiveness takes the behavioural-humanistic form (thesis 2).

The presented study should be a contribution to the discussion on shaping soft competitiveness as a form of detailed competitiveness of the organisation, where the quality of employees is emphasised in the overall operational and strategic development of the economic entity. 


\section{References}

Adamkiewicz-Drwiłło, H.G. (2002). Uwarunkowania konkurencyjności przedsiębiorstwa. Warszawa: Wydawnictwo Naukowe PWN.

Bailom, F., Matzler, K., \& Tschemernja, D. (2009). Jak utrwalić sukces. Co wyróżnia najlepsze przedsiębiorstwa? Warszawa: Wolters Kluwer.

Bieńkowski, W. (2000). Konkurencyjność gospodarki polskiej w przededniu wejścia do Unii Europejskiej: Czy rząd może być bardziej aktywny? In E. Latoszek (ed.), Unia Europejska wobec procesów integracyjnych. Wyzwania dla Polski. Conference proceedings. Warszawa: WSHiFM.

Budzanowska-Drzewiecka, M., Marcinkowski, A., \& Motyl-Adamczyk, A. (2016). Różnice kulturowe w komunikacji biznesowej. Kraków: Wydawnictwo Uniwersytetu Jagiellońskiego.

Cox, R. (2006). Posłowie. Bogaty plon Abrahama Maslowa. In A. Maslow, Motywacja i osobowość (trans. J. Radzicki). Warszawa: Wydawnictwo Naukowe PWN, pp. 367-369.

Gorynia, M. (ed.) (2002). Luka konkurencyjna na poziomie przedsiębiorstwa a przystapienie Polski do Unii Europejskiej. Poznań: Akademia Ekonomiczna.

Gorynia, M. (2009). Teoretyczne aspekty konkurencyjności. In M. Gorynia, E. Łaźniewska (eds.), Kompendium wiedzy o konkurencyjności. Warszawa: Wydawnictwo Naukowe PWN, pp. 48-66.

Hall, C.S., \& Lindzey, G. (2001). Teorie osobowości (trans. J. Kowalczewska, J. Radzicki). Warszawa: Wydawnictwo Naukowe PWN.

Jedynak, P. (ed.). (2010). Wiedza współczesnych organizacji. Wybrane problemy zarządzania. Kraków: Wydawnictwo Uniwersytetu Jagiellońskiego.

Kusz, D., Kusz, B., \& Sobolewski, M. (2009). Działalność inwestycyjna małych i średnich przedsiębiorstw w warunkach zmian otoczenia. In S. Lachiewicz, A. Zakrzewska-Bielawska (eds.), Zarządzanie organizacjami w warunkach konkurencyjnej gospodarki. Łódź: Politechnika Łódzka, pp. 356-365.

Lubiński, M. (1995). Konkurencyjność gospodarki czy przedsiębiorstwa. Gospodarka Narodowa, 6, 10-15.

Leśniewski, M.A. (2014). Konkurencyjność zasobowa przedsiębiorstw. Ekonomika i Organizacja Przedsiębiorstwa, (4), 57-68.

Leśniewski, M.A. (2015). Konkurencyjność miękka przedsiębiorstw. Warszawa: Difin.

Leśniewski, M.A. (2016). Świadomość ekorozwojowa w konkurencyjności miękkiej przedsiębiorstw. Edukacja Ekonomistów i Menedżerów, 2(40), 151-164.

Leśniewski, M.A. (2016a). The role of a manager in shaping behavioural cultural competitive advantage of the enterprises. Jagiellonian Journal of Management, 2(2), 115-134.

Łukomski, J. (2000). Próba zbudowania chrześcijańskiej etyki środowiska naturalnego. Kielce: Jedność.

Maslow, A.H. (2006). Motywacja i osobowość (trans. J. Radzicki). Warszawa: Wydawnictwo Naukowe PWN.

Matusewicz, C. (2006). Wprowadzenie do psychologii. Warszawa: Wizja Press \& IT.

McGee, R., \& Rennie, A. (2012). Budowanie zaangażowania pracowników. Zestaw narzędzi. Warszawa: Wolters Kluwer.

Miner, J.B. (2015). Organizational Behavior 1. Essential Theories of Motivation and Leadership. New York: Routledge Taylor \& Francis Group.

Oczkowska, R. (2014). Rozwój zasobów ludzkich - istota, instrumenty, podmioty. In R. Oczkowska, U. Bukowska (eds.), Rozwój zasobów ludzkich organizacji. Warszawa: Difin, pp. 11-30. 
Raiden, A.B., Dainty, A.R., \& Neale, R.H. (2007). Balancing employee needs, project requirements and organizational priorities in team deployment. Construction Management and Economics, 24(8), 883-895.

Rogers, C. (1991). Terapia nastawiona na klienta. Grupy spotkaniowe (trans. A. Dodziuk, E. Knoll). Wrocław: Thesaurus-Press.

Rolad-Lévy, Ch. (2004). W jaki sposób nabywa się pojęcia i wartości ekonomiczne. In T. Tyszka (ed.), Psychologia ekonomiczna. Gdańsk: Gdańskie Wydawnictwo Psychologiczne, pp. 284-286.

Stachowski, R. (2000). Historia psychologii: Od Wundta do czasów najnowszych. In J. Strelau (ed.), Psychologia (vol. 1). Gdańsk: Gdańskie Wydawnictwo Psychologiczne, pp. 40-45.

Stankiewicz, M.J. (ed.) (2006). Zarządzanie wiedzą jako kluczowy czynnik międzynarodowej konkurencyjności przedsiębiorstwa. Toruń: Dom Organizatora.

Suchowierska, M. (2008). Stosowana analiza zachowań - wykorzystanie technik behawioralnych do rozwiązywania problemów społecznych. In P. Bąbel, P. Ostaszewski (eds.), Współczesna psychologia behawioralna. Kraków: Wydawnictwo Uniwersytetu Jagiellońskiego, pp. 239260.

Świtalski, W. (2005). Innowacje i konkurencyjność. Warszawa: Wydawnictwa Uniwersytetu Warszawskiego.

Taormina, R.J. (2009). Organizational socialization: The missing link between employee needs and organizational culture. Journal of Managerial Psychology, 24(7), 650-676.

Trojan, M. (2014). 100-lecie manifestu behawiorystycznego Johna Watsona, retrieved from: maciejtrojan.natemat.pl [accessed: 19.06.2017].

Tyszka, T., \& Zaleśkiewicz, T. (2004). Psychologia pieniądza. In T. Tyszka (ed.), Psychologia ekonomiczna. Gdańsk: Gdańskie Wydawnictwo Psychologiczne, pp. 174-176.

Ziółkowska, A.M. (2008). Osobowość w ujęciu psychologii behawioralnej. In P. Bąbel, P. Ostaszewski (eds.), Współczesna psychologia behawioralna. Kraków: Wydawnictwo Uniwersytetu Jagiellońskiego, pp. 154-157.

\section{Note about the Author}

Michą A. Leśniewski, Ph.D. - doctor of economic sciences in the field of management. He works at the Department of Management, the University of Jan Kochanowski in Kielce. His current research interests include soft management issues, soft competitiveness, cultural competitiveness, organizational culture and positive potential of organisations. He collaborates with such scientific journals as Ekonomika i Organizacja Przedsiębiorstwa and Przeglą Organizacji. He is the author of the monograph entitled Konkurencyjność miękka przedsiębiorstw [Soft Competitiveness of Enterprises] (2015). Warszawa: Difin. 